\title{
Is sexually transmitted fungal infection evidence for size-related mating success in Neotropical guava fruit flies?
}

\author{
Ingemar Hedström ${ }^{1}$ and Julián Monge-Nájera ${ }^{2}$
}

1 Department of Applied Science, Mid Sweden University, S-871 88 Härnösand, Sweden, Ingemar.Hedstro@tnv.mh.se 2 Escuela de Biología, Universidad de Costa Rica, 2060 San José, Costa Rica, julianm@ cariari.ucr.ac.cr

Recibido 24-IV-1998. Corregido 21-VII-1998. Aceptado 14-VII-1998

\begin{abstract}
The influence of wing length on mate preference was examined in natural populations of the Neotropical guava fruit fly, Anastrepha striata Schiner, at two locations in Costa Rica. Based on evidence that the fungi are transmitted during mating, site-specific infection by Laboulbeniales fungi on the body surface was used to assess mating history. At both sites, males and females that carried fungi on the legs and/or on the ventral part of the thorax (males), and on both sides of the notum and/or the dorsal base of the abdomen (females); had significantly longer wings than males and females without fungi. This suggests that individuals of both sexes with longer wings (i.e. larger individuals) enjoy higher mating success. Fungus infection is more frequent in the wet than in the seasonally dry forest, possibly because hosts are available year-round in the wet forest.
\end{abstract}

Key words: Mate choice, female choice, Tephritidae, fungi, infection.

Sexual selection as an important evolutionary force, first proposed by Darwin (1871), has attracted increased attention during the last two decades (Thornhill \& Alcock 1983, Gwynne \& Morris 1983, Bradbury and Andersson 1987, Fincke 1997). Although many variables seem to be involved, perhaps the single most important factor affecting intrasexual selection among males in insects is body size (Thornhill \& Alcock 1983).

Previous studies by the senior author in Costa Rica and Guatemala (Hedström 1994) have shown that fruit flies of the species Anastrepha striata Schiner are frequently infected by laboulbenial fungi of the genus Stigmatomyces; and it has also been established that transmission occurs during copulation (Fig. 1), either completed or attempted.
Relatively small insect males are often less able to capture and defend a resource that promotes reproductive success than are large rivals. Tephritid fruit flies are no exception. Burk (1983) demonstrated in the Caribbean fruit fly Anastrepha suspensa (Loew) that resident males, especially larger ones, tend to win fights with intruders. Hendrichs (1986) found that large laboratory-reared A. suspensa males were more successful in competing for and mating with females. Other research has shown that large fruit flies are at an advantage with respect to increased flight ability (Sharp et al. 1983, Bloem et al. 1994) and mating frequency in laboratory tests (Churchill-Stanland et al. 1986).

In general, Anastrepha species, when not visiting fruits, spend a great deal of time on the 

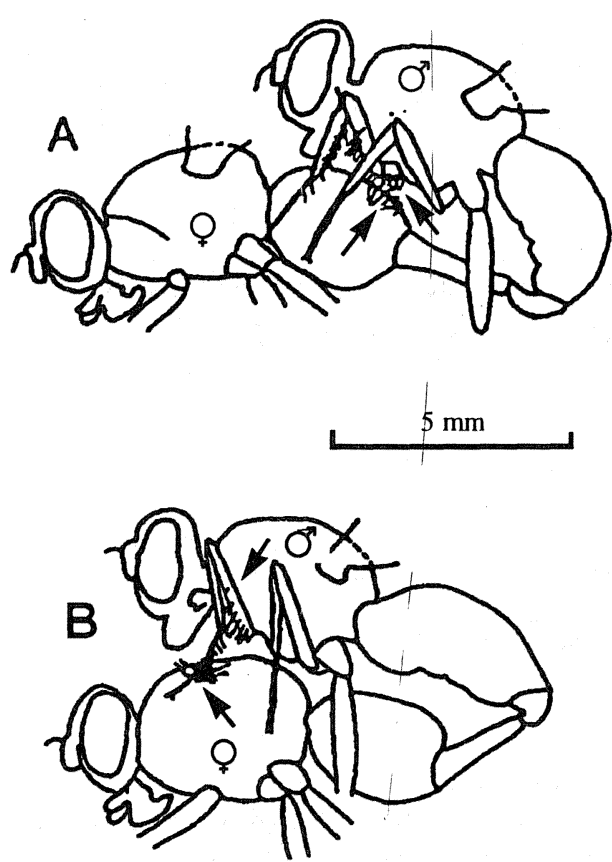

Fig. 1. Positions of male and female of the Anastrepha striata fruit fly during mating. Transmission of Laboulbeniales fungi of the genus Stigmatomyces occurs between $(A)$ the ventral side and the thorax of the male of the dorsal side of the abdomen of the female, and (B) the front legs of the male and the sides of the female notum.

underside of leaves, and despite elaborately patterned wings are easily overlooked by the researcher in the field. This fact, along with their movements among individual host trees, makes them difficult to observe in their natural environment. Fruit fly researchers have tried to overcome this problem by maintaining close-to-natural conditions in cages over host plants (e.g. Dodson 1982). With few exceptions, studies of mating behavior of tephritids have therefore been conducted in manipulated conditions in the field, in the laboratory, or with laboratory reared flies released into caged host trees in the field (Prokopy \& Hendrichs 1979). While these methods have allowed detailed descriptions of behavior, they need to be supplemented with observations under completely natural conditions.

Here, we report the effects of body size on mating success in natural populations of the guava fruit fly, using as probable evidence the occurrence of infection by sexually transmitted Stigmatomyces aciurae Thaxter and $S$. verruculosus Thaxter fungi (Laboulbeniales). In particular, we asked the following question: Is the infection more prevalent in certain size classes of (1) males and (2) females compared to other size classes? If so, is this evidence of preference for larger mates in guava fruit flies?

\section{MATERIALS AND METHODS}

Adult A. striata fruit flies were collected with standard McPhail invaginated glass traps containing $4 \%$ ammonium acetate and borax in water at two locations within a non-seasonal, tropical wet forest environment: an abandoned guava (Psidium guajava L.) (Myrtaceae) orchard at Guácimo $\left(10^{\circ} 14^{\prime} \mathrm{N} ; 83^{\circ} 59^{\prime} \mathrm{W}\right)$ (elev. $120 \mathrm{~m}$ ), Limón Province, Costa Rica, once a week, from 15 March to 1 April 1987, and from 7 to 27 February 1993; and an unsprayed guava orchard at the Tropical Agronomy Teaching and Research Center (CATIE), Turrialba (09 $55^{\prime} \mathrm{N}$; $83^{\circ} 41^{\prime} \mathrm{W}$ ) (elev. $600 \mathrm{~m}$ ), Cartago Province, Costa Rica, on a weekly basis, from 14 September to 12 November 1989.

The collected flies in both study sites were pooled, and wing lengths [as the length from the base of the first costal cell to the tip of the wing ( $c f$. Foote 1980)] were measured to the nearest $0.05 \mathrm{~mm}$, using an eyepiece micrometer. A light microscope was used in the laboratory to detect perithecia of Stigmatomyces fungi externally on legs and/or the ventral part of the thorax (males), and on both sides of the notum and/or the dorsal base of the abdomen (females). The number of guava fruit flies with and without fungal infection was tallied. Mann Whitney $U$-Tests were used in the statistical analysis.

\section{RESULTS}

Both males $(n=52)$ and females $(n=50)$ carrying Stigmatomyces fungi had significantly 
longer wings than males $(\mathrm{n}=110)$ and females (n=102) without fungi (males: $U=3747, P=$ 0.001; females: $U=3225, P=0.008$ ) (Fig. 2).

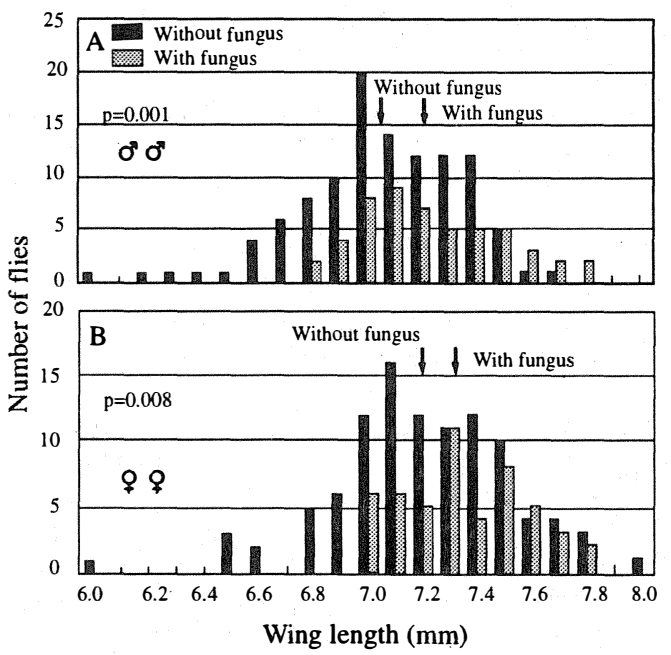

Fig. 2. Comparison of mean wing lengths of Anastrepha striata fruit flies with and without laboulbenial fungi. Arrows indicate the means of the distributions. (A) Males (without fungi: $7.06 \pm 0.30 \mathrm{~mm}$; with fungi: $7.24 \pm 0.26$ $\mathrm{mm}$ ). (B) Females (without fungi: $7.20 \pm 0.32 \mathrm{~mm}$; with fungi: $7.34 \pm 0.23 \mathrm{~mm}$ ). Mann-Whitney U-test.

\section{DISCUSSION}

Insect size and fungus occurrence: Since the fungi presumptuously are transferred between the sexes during copulation, we interpret the probability of infection as an indication of relative mating success. If longer wings characterize larger individuals, our data suggest that male and female A. striata preferentially mate with larger individuals. Of course, a stronger test of a size-assortative mating pattern requires a study of sperm transfer.

Prokopy (1984) suggested that for Anastrepha species, a single mating usually provides a sufficient amount of sperm to last for several weeks, if not an entire lifetime, and noted that females usually resist further mating attempts following initial copulation. However, Teles da Silva et al. (1985) showed that $A$. obliqua (Macquart) and $A$. bistrigata
Bezzi are polygamous; male and female $A$. bistrigata were found to copulate several times: one male was observed to mate 15 times, and one female 13 times. The largest number of repeated matings observed in $A$. obliqua was three for a male and two for a female (Teles da Silva et al. 1985).

Because fungus transmission requires contact between sexes, infected females or males that copulate only once, or females that are mounted by males in an attempt to copulate only once, represent dead-end hosts for the fungus (Hedström 1994). Thus, either $A$. striata females are mounted more than once, and/or males are polygynous.

Habitat type and fungus occurrence: In non-seasonal, tropical wet forests (like the Costa Rican forest considered in this study), a permanent presence of host guava fruits for $A$. striata allows generations to overlap, which contributes to a high incidence of fungi (Hedström 1994). In contrast, the periodic absence or scarcity of host fruits in seasonal, tropical moist forests, as well as in tropical dry forests, probably explains the lower frequency or absence of fungus infections in those habitats. Subsequent collections of detailed data on seasonal population dynamics of $A$. striata fruit flies (Hedström 1993) support the suggestion that the high rate of fungal infection in wet environments is maintained because host flies are continuously present.

The causes and ecology of Laboulbeniales fungus infection are still poorly understood. Further research should consider questions such as: Do fungi-infected females carry more spermatophores? Could larger infected flies be preferred for mating because the fungi liberate a sinomone (W. Ramírez, pers. com.)? and Does fungal infection affect Anastrepha' fecundity?

\section{ACKNOWLEDGMENTS}

We thank R. Thornhill, S. Ulfstrand, J. Sivinski, T. Herman, W. Ramírez, A. 
Balmford, Bo W. Svensson and two anonymous reviewers for helpful comments on the manuscript. The study was partly financed by the Royal Swedish Academy of Sciences, the Foundation of Zoological Research of Uppsala University, and Mid Sweden University.

\section{RESUMEN}

Se estudió poblaciones naturales de la mosca frutera Anastrepha striata Schiner, en dos lugares de Costa Rica. Los hongos Laboulbeniales se transmiten en éstas durante la cópula. Hembras y machos con hongos en las patas y/o parte ventral del tórax (machos), y en ambos lados del noto y/o base dorsal del abdomen (hembras), tenían alas significativamente más largas que los individuos no parasitados. Esto sugiere que los individuos más grandes logran más apareamientos.

\section{REFERENCES}

Bloem, K. A., S. Bloem \& D. L. Chambers. 1994. Field assessment of quality: Release-recapture of mass-reared Mediterranean fruit flies (Diptera: Tephritidae) of different sizes. Environ. Entomol. 23: 629-633.

Bradbury, J. W. \& M. B.Andersson (eds.). 1987. Sexual Selection: Testing the Alternatives. Wiley, New York.

Burk, T. 1983. Behavorial ecology of mating in the Caribbean fruit fly, Anastrepha suspensa (Loew). Florida Entomol. 66: 330-344.

Churchill-Stanland, C., R. Stanland, T.T.Y. Wong, N. Tanaka, D.O. McInnis \& R. V. Dowell. 1986. Size as a factor in the mating propensity of Mediterranean fruit flies, Ceratitis capitata (Diptera: Tephritidae), in the laboratory. J. Econ. Entomol. 79: 614-619.

Darwin, C. R. 1871. The Descent of Man, and Selection in Relation to Sex. Murray, London

Dodson, G. 1982. Mating and territoriality in wild Anastrepha suspensa (Diptera: Tephritidae) in field cages. J. Georgia Entomol. Soc. 17: 189-200.
Fincke, O.M. 1997. Conflict resolution in the Odonata: implications for understanding female mating patterns and female choice. Biol. J. Linn. Soc. 60: 201-220.

Foote, R.H. 1980. Fruit Fly Genera South of the United States (Diptera: Tephritidae) United States Dep. of Agriculture, Washington D. C.

Gwynne, D. T. \& G. K. Morris. (eds). 1983. Orthopteran Mating Systems. Sexual Competition in a Diverse Group of Insects. Westview, Boulder, Colorado.

Hedström, I. 1993. Population dynamics and host relationships of neotropical fruit flies (Diptera: Tephritidae) in seasonal and non-seasonal environments. Int. J. Pest Manage. 39: 400-410.

Hedström, I. 1994. Stigmatomyces species on guava fruit flies in seasonal and non-seasonal tropical forest environments. Mycol. Res. 98: 403-407.

Hendrichs, J. P. 1986. Sexual selection in wild and sterile Caribbean fruit flies, Anastrepha suspensa (Loew) (Diptera: Tephritidae). M.S. thesis, University of Florida, Gainesville.

Prokopy, R.L. 1984. Foraging behaviour of true fruit flies. Am. Scientist 72: 41-49.

Prokopy, R. L. \& J. Hendrichs, 1979. Mating behaviour of Ceratitis capitata on a field-caged host tree. Am. Entomol. Soc. 72: 642-648.

Sharp, J. L., Boller, E. F. \& D. L. Chambers, 1983. Selection for flight propensity of laboratory and wild strains of Anastrepha suspensa and Ceratitis capitata (Diptera: Tephritidae). J. Econ. Entomol. 76: 302305 .

Teles da Silva, M., Polloni, Y.J. \& Bressan, S. 1985. Mating behavior of some fruit flies of the genus Anastrepha Schiner, 1868 (Diptera: Tephritidae) in the laboratory. Revta. Bras. Entomol. 29: 155164.

Thornhill, R. \& J. Alcock, 1983. The Evolution of Insect Mating Systems. Harvard University, Cambridge. 